\title{
Undergraduates' Experiences and Perceptions of a Problem-based Learning Approach in ESL Writing Classroom
}

\author{
Muhammad Mukhtar Aliyu \\ Bauchi State University, Gadau-Nigeria \\ mamukhtar@basug.edu.ng \\ Yong Mei Fung \\ Universiti Putra Malaysia, Malaysia \\ Sabariah Md Rashid \\ Universiti Putra Malaysia, Malaysia \\ Vahid Nimehchisalem \\ Universiti Putra Malaysia, Malaysia \\ DOI: https://doi.org/10.36892/ijlls.v2i1.144
}

$\begin{array}{ll}\begin{array}{l}\text { Received: } \\ \text { 25/12/2019 }\end{array} & \text { Abstract } \\ & \text { This study investigates Nigerian undergraduates experiences of a } \\ \text { Accepted: } & \text { problem-based learning approach }(P B L) \text { in an ESL writing classroom. The } \\ \text { 15/3/2020 } & \text { Composition course. A questionnaire was used to collect data on the } \\ & \text { participants experiences and perceptions of PBL. Semi-structured } \\ \text { Keywords: } & \text { interview and reflective journal were also employed to substantiate the } \\ \text { Experience, ESL } & \text { quantitative data. The overall findings of the study show that the } \\ \text { Classroom, Nigerian } & \text { participants had positive experiences and perceptions. They had positive } \\ \text { Undergraduates, PBL, } & \text { experiences and perception of the ill-structured problem, facilitation and } \\ \text { Writing Skills } & \text { problem-solving process. The findings also show that the approach had a } \\ & \text { positive impact on the participants' writing skills as well as other language } \\ & \text { skills. Other pedagogical implications which would give insight for better } \\ & \text { implementation of the PBL approach are presented in the study. }\end{array}$

\section{INTRODUCTION}

In language instruction, instructors have been looking for a method that would enable their students to acquire the required skills. This is because the traditional teacher-centred method fails to give the desired goal, as many students only know about a language but not how to use it (Mardziah H. Abdullah, 1998). For instance, teaching writing has been a challenging area for both teachers and students. The challenges are heightened particularly for second language (L2) learners due to limited linguistic competence, such as appropriate English lexical expressions, mechanics, grammar and sentence structure (Xiao, 2007). As the result, instructors need a more effective and comprehensive writing instruction to help their students. In Nigeria, for example, English is used as an L2, for official, and the language of instructions at all levels of education. In addition, the rapid increase in the interactions of Nigerians with the international world, either for educational or commercial purposes, 
necessitates the need for proficiency in writing in English. However, many Nigerian many undergraduates have difficulties in their writing (Bodunde \& Sotiloye, 2013; Olusoji, 2013; Theodore, 2013) as the result of the ineffective methods adopted by the instructors who give little or no attention to what the students do in the writing process or how they write (Muodumogu \& Unwaha, 2013). As a result, the students show little or no improvement in their writing (Obi-Okoye, 2004). Most of the traditional methods adopted by the teachers are largely due to the lack of alternative approaches that have been proven effective in enhancing students' writing skills (Babalola, 2012). This shows the need to investigate the effectiveness of other learning approaches in order to provide solutions to the problems of teaching and learning of writing in the Nigerian context.

Researchers have shown that language is learned best in a natural setting, when it is used to perform real-life tasks and through collaboration. For example, in writing classrooms, students should learn the actual writing not only learn about writing. Teachers and peers should support students throughout the writing process by looking at both the writing process and product (Graham \& Harris, 2009). Many scholars have adopted various methods in order to develop students' writing skills (Rashtchi \& Mohammadi, 2017). One instructional approach proven effective in developing students' skills is problem-based learning approach (PBL).

PBL is an instructional approach which contextualises learning in a real-life situation. It is developed in order to improve students' learning output alongside other skills such as critical thinking, problem-solving skills through collaborative work to solve a real-life problem. Students work in small groups to decide and discover for themselves what and how they will learn, and propose viable solutions to an ill-structured problem. Tutors only guide the students in the process through open-ended questioning (Mardziah H. Abdullah, 1998) unlike in the traditional teacher-centred approach where tutors dispense the content of the curriculum (Wilkerson \& Gijselaers, 1996). The ill-structured problem given to the students serves as a trigger of their inquiry, which leads them to the discovery of relevant knowledge and skills required to solve or understand the problem. The ill-structured problem is defined as a problem related to the students' real-life situation which does not have a straightforward answer (Jonassen, 1997).

Adopting PBL in the writing classroom may have some advantages for both teachers and students. For the students, it gives them opportunities to be actively engaged in the writing process. Students may find the brainstorming process easier and more effective as the illstructured problem is based on their real-life situation which they all have first-hand experiences. This would make it easier for them to retrieve information from the long-term memory and stimulate discussion among them as everyone provides his/her personal experiences. It may also minimise their anxiety while maximising their motivation and interest in the process.

Previous studies conducted on PBL, in different countries and in various field, have shown its effectiveness in developing students' learning skills. These include acquisition of subject content/knowledge (Hande, Mohammed \& Komattil, 2014), life-long learning (Hosseini \& Assareh, 2011), critical thinking (Yuan et. al, 2008), problem solving skills (Bigelow, 2004) and language skills (Mardziah H. Abdullah \& Tan, 2008; Norzaini Azman \& Shin, 2012; Othman \& Ismail Ahamad Shah, 2013). Despite the effectiveness of problem-based learning approach in enhancing students' learning achievements and other skills, it may confuse both students and teachers when there are problems in its design or implementation 
(Tan, 2004). Thus, there is the need for the proper design and implementation of PBL in classrooms in order to achieve the desired goals.

From the discussion so far, the following research gaps are identified. Firstly, the effectiveness of PBL in developing students' learning skills depends on how well it is delivered (how well an ill-structured problem is presented, how well students conduct themselves in the learning process, and how well tutors facilitate the students in the problem-solving process). These have not been investigated in ESL writing classrooms.

Secondly, although PBL has been carried out Western and Asian contexts in various fields, Nigerian undergraduate students have not been introduced into PBL particularly in an ESL writing classroom. Thus, the findings in the western and Asian contexts cannot be generalised to or be applicable in the Nigerian educational context due to the differences in the educational settings, social and cultural values.

Therefore, this study hopes to propose PBL as a new approach to the teaching of writing in Nigeria. To achieve that, there is a need to investigate Nigerian students' experiences and perceptions of PBL in a writing classroom, as students' experiences influence their performance (Gustilo, 2013). Accessing their experiences and perceptions of PBL would allow the researchers to make recommendations for the better implementation of the approach not only in a writing classroom but also in other aspects of language. In language learning, students' attitudes which involve their feelings and beliefs play a significant role in determining their success (Ansarimoghaddam \& Tan, 2014).

\section{PURPOSE OF THE STUDY}

The purpose of the study is to find out the experiences and perceptions of Nigerian undergraduates in writing classroom using a PBL approach in order to propose an effective method to writing instruction for Nigerian teachers. Specifically, the study aims to explore students' experiences and perceptions of the ill-structured problem presented to them, the facilitation process and the problem-solving process. It also includes experiences of PBL in relation to writing and other language skills.

\section{RESEARCH QUESTION}

The following research question was formulated to guide the study

What are the students' experiences and perceptions of using PBL approach in a writing classroom?

\section{METHODOLOGY}

\section{Participants of the Study}

An intact class of second-year undergraduate students $(n=18)$ taking a compulsory course of English Composition was selected for the study. The participants were of mixed-gender and their ages ranged from 24-36 years old. The participants were divided into smaller groups of five participants each.

\section{Instruments}

Two types of data, quantitative and qualitative, were collected for the study using different instruments. A questionnaire on PBL experiences was used to collect the quantitative data. The PBL questionnaire was adapted from Tan (2004). It comprises 36 closed-ended items designed in a Likert scale form (see Appendix A). It was administered to the participants at the 
end of the PBL activities to elicit their experiences and perceptions of the use of PBL in the writing classroom. The questionnaire was divided into 6 six sections. Section 1 elicits background information. Section 2 obtains the participants' experiences regarding the illstructured problems presented during the PBL activities. Section 3 elicits data on the participants' experiences of tutor facilitation process. Section 4 gathers their experiences as problem-solvers. Section 5 collects the participants' experiences of PBL in relation to writing. Finally, section 6 collects information on the participants' experiences of PBL in relation to other language skills of language. Sections 1, 5 and 6 were added to the original questionnaire to suit the present study. The sections were added because Tan's study was not in the field of language while the present study was a language-based one. Thus, the modifications enabled the researcher to ascertain the participants' perceptions of the PBL approach in relation to their writing skills and other incidental benefit of PBL in related to their language skills in general. The questionnaire was validated by a panel of three experts who lecturers and researchers from a local university in Malaysia to ensure its validity (Creswell, 2012). To ensure reliability, the questionnaire was piloted before the actual study. The cronbach's Alpha coefficient of the pilot study is 0.93 while that of the actual study is 0.96 . These values are acceptable as values greater than 0.7 are considered reliable (George \& Mallery, 2003).

To collect the qualitative data, the participants were asked to write reflective journals at the end of each PBL session. A semi-structured interview was also conducted with all the participants at the end of the whole PBL process. The interview contains open-ended questions designed to elicit information regarding the participants' experiences of the ill-structured problem, peer collaboration, facilitation, and effects of PBL on their writing process, and with other language skills.

\section{Research Procedures}

The PBL treatment was given to the participants in two cycles. In each cycle, an illstructured problem (see Appendix B) was given to the participants to propose viable and plausible solutions in three weeks. In the first week, the first ill-structured problem which is about involvement of some students in terrorism in Northern Nigeria was presented to the participants and they were asked to propose viable solutions (in an essay form) following Savery and Duffy (1995) model of PBL. The stages are as follows:

1. Generate working ideas or possible solutions;

2. Identify available information related to the problem;

3. Identify learning issues (things about which they need to find more information);

4. Identify resources to look up or consult;

5. Assign tasks to the various group members (i.e., share the learning issues);

6. Gather information (conduct self-directed learning); and

7. Propose solution(s).

In the second week, every group member presented his/her findings to their respective groups. Every group discussed its findings, criticised the source of the information too. They further identified more learning issues on some items with which they were not satisfied, and finally drafted proposed solutions to the ill-structured problem. In the third week, every group reviewed, edited their draft and redrafted the solutions. During the group discussion, two tutors who were lecturers in a university in Nigeria facilitated the participants learning through openended questioning. Finally, every group presented its findings to the class. After taking 
corrections and observations from peers and tutors, every group made the corrections and submitted the proposed solutions to the researcher.

After the cycle, a debriefing session was conducted by the tutor to discuss writing and PBL-related issues with the participants. The same procedures were repeated for the second cycle using an ill-structured problem on Nigerian undergraduates' excessive engagement with social media, which negatively affected their academic performance.

\section{RESULTS AND DISCUSSION}

The data collected in the study involve both quantitative and qualitative data. The following sections present the results from the questionnaire which was substantiated by the findings gathered from the semi-structured interview.

\section{Participants' Experiences of Solving the Ill-Structured Problems}

The participants were asked to evaluate the experiences of the ill-structured problems presented to them during the PBL process. Overall, the results show that the participants had positive experiences about the ill-structured problems. The participants recorded the highest mean score $(\mathrm{M}=4.77)$ for item 6 where $77.8 \%$ of them strongly agreed that they learned much through solving the ill-structured problems. It is revealed that $55.6 \%$ strongly agreed that they were engaged in thinking and learning throughout the PBL cycles $(M=4.33)$. This may be connected to the fact that they found the ill-structured problems well presented in terms of reallife situation $(\mathrm{M}=4.55)$ in which $55.6 \%$ of them strongly agreed. Also, 61.1\% $(\mathrm{M}=4.61)$ and $50 \%(\mathrm{M}=4.38)$ agreed that they found the ill-structured problems meaningful to the acquisition of relevant skills and knowledge for their course respectively. As a whole, the participants were not only interested in ill-structured problems, but also motivated to engage in solving other ill-structured problems in the future (4.44) as 55.6\% of them agreed on. Table 1 presents the summary of the result.

Table 1: Participants' Experiences of the Ill-structured Problem

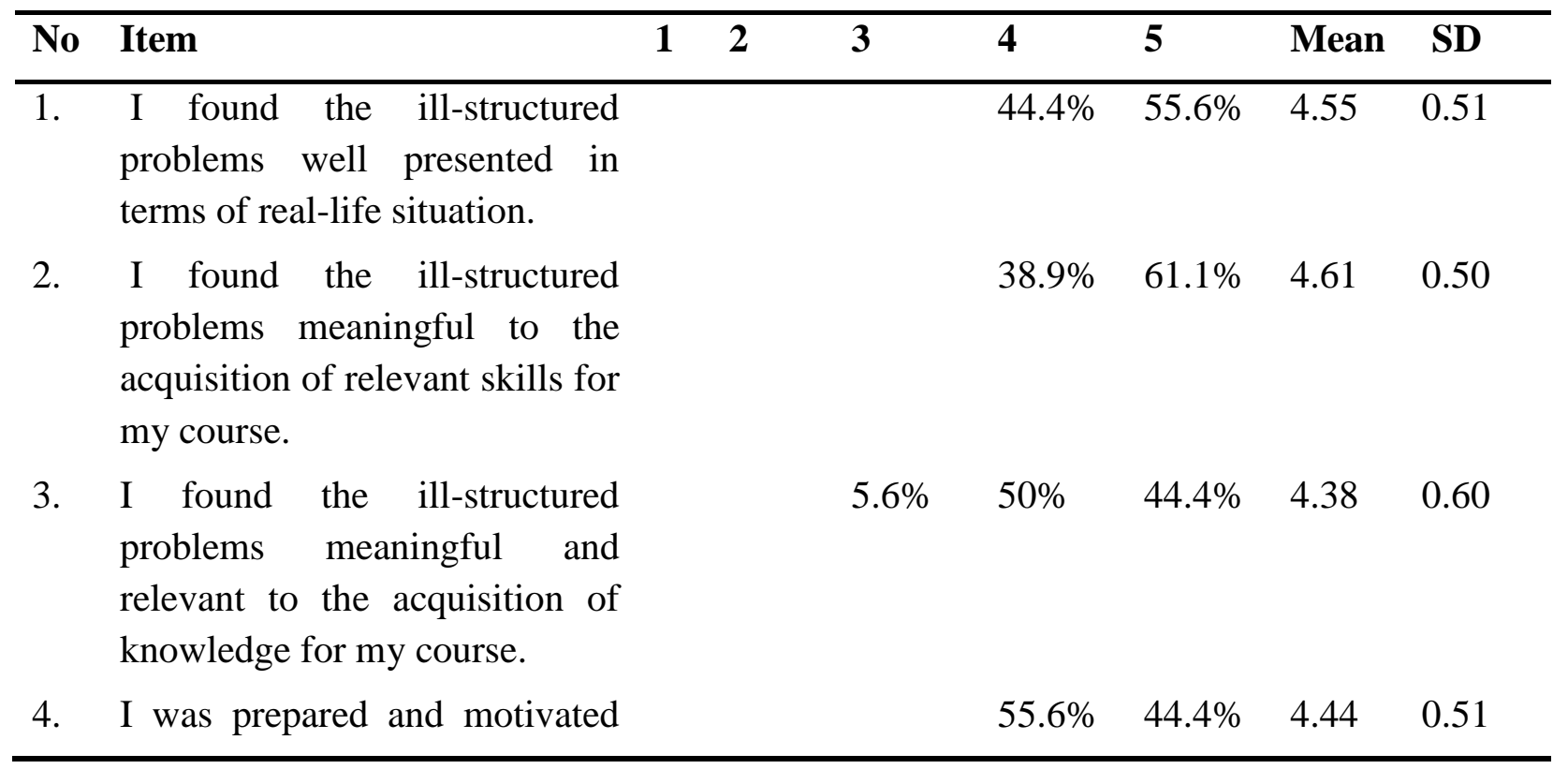




to work on the ill-structured
problems.
The problems engaged my $5.6 \%$
$\begin{aligned} & \text { The } \\ & \text { learning and thinking } \\ & \text { throughout the PBL cycles. }\end{aligned}$
I learned much through the
experience of solving the ill-
structured problems.

The responses obtained from the semi-structured interview also showed the participants' positive experiences with the ill-structured problems. The participants responded that the ill-structured problems motivated them and made them generate more ideas. This is because the ill-structured problems were related to their real-life situation. In addition, the illstructured problems helped them to acquire new knowledge and encouraged them to learn various types of writing such as essays and report writing which are parts of their course of study.

For instance, Ishaq explained that the ill-structured problems motivated his group during the PBL session because the problems were interesting and related to their real-life. This allowed them to contribute freely and exchange ideas during the discussions.

The activity is very interesting because it's related to us and made each and every one of us free to talk and also give his or her contribution.

On whether the ill-structured problems allowed them to acquire new knowledge, Umar mentioned that during the self-directed learning he learned how to write an article for newspaper publication which is part of the requirements of his course of study. This is because the ill-structured problem required them to write an article in proposing viable solutions.

During the last session, I was opportune to learn how to write an article properly, the rules guiding article writing and I developed some vocabularies.

For Babayo, the PBL activities encouraged him learn how to write a cause-effect essay. Similarly, on the acquisition of new knowledge related to their course content, Yunus reported that he learned how to write a proposal letter. He was assigned to study the format of a proposal letter by his group as his learning issue during the self-directed learning. These findings are in line with findings of previous studies which show that students become more motivated when they believe that the outcome of learning is under their control (Bandura, 1997). The findings also concur with those of the other studies that PBL increased students' motivation in learning (Norman \& Schmidt, 2000; Tarmizi \& Bayat, 2010) found it more interesting, stimulating and useful (Schmidt, Dauphinee, \& Patel, 1987) as the result of setting their own learning (Zimmerman, 1989). 


\section{Participants' Experiences of Tutor Facilitation Process}

With regard to the tutor facilitation process, the results revealed that the participants also had positive experiences. Majority of the participants $(77.8 \%)$ found the facilitation process helpful throughout the PBL process, as indicated in item 2 with the highest mean of 4.77. This corresponds with item $3(M=4.77)$ which also shows that $77.8 \%$ of the participants strongly agreed that they found the tutors' encouragement of inquiry and questioning helpful in the PBL process. These are followed by the item $1(\mathrm{M}=4.72)$ which reveals that $72.2 \%$ of the participants strongly agreed that the tutors were confident and knew what they were doing to facilitate their learning in the PBL process. This may as the result of the tutors playing helpful roles in facilitating the participants' acquisition of problem-solving skills $(\mathrm{M}=4.55)$, new knowledge $(\mathrm{M}=4.50)$ and integration of new knowledge $(\mathrm{M}=4.61)$ which majority of them, $66.7 \%, 50 \%$ and $61.1 \%$ strongly agreed with respectively. Table 2 presents the mean scores of the six items evaluating the participants' experiences of the facilitation process.

\section{Table 2: Participants' Experiences of the Tutor Facilitation Process}

\begin{tabular}{lllllll}
\hline No Item & $\mathbf{1}$ & $\mathbf{2}$ & $\mathbf{3}$ & $\mathbf{5}$ & Mean & SD \\
\hline 1. & $\begin{array}{l}\text { The tutors were confident and knew what } \\
\text { they were doing to facilitate my learning } \\
\text { in the PBL process. }\end{array}$ & & $27.8 \%$ & $72.2 \%$ & 4.72 & 0.46 \\
2. I found the tutors' facilitation throughout \\
the various PBL stages helpful.
\end{tabular}

The participants' responses of the semi-structured interview also showed their positive experiences of the facilitation process. The findings revealed that the tutors guide and supported them throughout the PBL sessions. For example, according to Khadija, her tutors guide her group to have a better understanding of the ill-structured problem.

Our tutor supports us in many ways one of which is in the first place we did not get the question [the ill-structured problem] 
right he is the one that guide us and we come to understand the question better.

Furthermore, it is revealed that the tutors encouraged the participants to speak whenever they felt nervous during the interactions. This in turn helped them to improve their speaking skills as explained by Habib.

Our tutors help us by encouraging us to speak our minds that there is nothing like a good idea or bad idea in PBL.

Jibrin explained that the tutors helped them during the PBL session through asking them open-ended questions which made them think of more ideas and from different perspectives. As for Amir, his tutors did not only help them to actualise their problem-solving skills and learn about writing but also help them to realise their potentials of becoming better learners.

\section{Participants' Experiences of the Problem-solving Process}

The results of the questionnaire also revealed that the participants had positive perceptions of the ill-structured problem. The participants strongly agreed that they become more independent and self-directed learners as shown in item $1(\mathrm{M}=4.72), 77.8 \%$. In addition, $72 \%$ of the participants strongly agreed that they learned to think more deeply in solving an illstructured problem through the collaborative and co-operative approaches as shown in items 3 $(\mathrm{M}=4.72)$ and $7(\mathrm{M}=4.72)$. This may be explained in item two $(\mathrm{M}=4.50)$ as $50 \%$ of the participants strongly agreed that they learned to take different perspectives in solving the illstructured problem, and item $4(\mathrm{M}=4.55)$ where $55.6 \%$ strongly agreed that they learned to access a variety of resources and information in solving the ill-structured problems. Item 6 (M $=4.38$ ) shows that $61.1 \%$ of the participants agree that they were more prepared and ready to solve more complex ill-structured problems. This showed the participants' positive experiences with regard to the ill-structured problem. Table 3 below presents the summary of the results.

Table 3: Participants' Experiences of the Problem-solving Process

\begin{tabular}{|c|c|c|c|c|c|c|}
\hline No & Item & 123 & 4 & 5 & Mean & $\overline{\text { SD }}$ \\
\hline 1. & $\begin{array}{l}\text { I learned to become a more independent and } \\
\text { self-directed learner. }\end{array}$ & $5.6 \%$ & $16.7 \%$ & $77.8 \%$ & 4.72 & 0.57 \\
\hline 2. & $\begin{array}{l}\text { I learned to take different perspectives in } \\
\text { solving an ill-structured problem. }\end{array}$ & & $50 \%$ & $50 \%$ & 4.50 & 0.51 \\
\hline 3. & $\begin{array}{l}\text { I learned to think more deeply in solving an ill- } \\
\text { structured problem. }\end{array}$ & & $27.8 \%$ & $72.2 \%$ & 4.72 & 0.46 \\
\hline 4. & $\begin{array}{l}\text { I learned to access a variety of resources and } \\
\text { information in solving an ill-structured } \\
\text { problem. }\end{array}$ & & $44.4 \%$ & $55.6 \%$ & 4.55 & 0.51 \\
\hline 5. & $\begin{array}{l}\text { I learned to explore a variety of resources and } \\
\text { information in solving an ill-structured }\end{array}$ & & $44.4 \%$ & $55.6 \%$ & 4.55 & 0.51 \\
\hline
\end{tabular}


problem.

6. Through the PBL process I am more prepared

$61.1 \% \quad 38.9 \% \quad 4.38 \quad 0.50$ and ready to solve more complex ill-structured problems.

7. I learned much through the collaborative and $27.8 \% \quad 72.2 \% \quad 4.72$ 0.46 co-operative approaches.

In addition to the results of the questionnaire, the participants' responses in the semistructured interview also showed their positive responses. It is revealed that the participants learned to think from various perspectives, and share ideas among themselves while solving an ill-structured problem. For instance, Samuel explained that of all the benefits from the PBL approach, the greatest is the development of his critical thinking skills. In order to propose viable solutions to an ill-structured problem, they were required to think critically on the causes and solutions to the problem.

The greatest thing I learn in the activities was the development of my critical thinking skills because in the attempt to generate possible causes and solutions to an ill-structured problem we need to think critically.

For others like Amina, she did not only interact and share ideas with her group members but also learned to think to be creative in her thinking.

I learned how to interact with other members of my group to think and express my thought in the best possible way and also improve my creativity.

In addition to the development of the participants' thinking skills, the problem-solving process encouraged them to conduct self-directed learning and research on certain issues. This is because the ill-structured problems were interesting and motivating as they are related to the participants' real life. This stimulated their quest and enthusiasm for more information. Ismail explained that he felt like becoming a journalist who would be investigating issues and reporting because he was requested to ask for people's opinion on terrorism during the selfdirected learning.

I now feel like becoming a journalist because it allows people to conduct research on a matter to collect genuine fact and finally write down their findings.

For other participants like Justina and Jibril, the self-directed learning process gave them opportunities to interact with other people who have different characters. Jibril explained that he acquired more knowledge on how to carry out a research, particularly how to conduct an interview with people. The interactions and the responses given to him by different respondents during the self-directed learning encouraged and motivated him. 
In addition to the interview skills, the participants also learned cooperative work during the problem-solving process. Umar revealed that he learned to play the roles of leaders and follower and to respect other's views. According Jibril, he also learned the importance of teamwork in learning because it would enable students to develop their language skills.

I learned that working in a group is of paramount importance [for learning] because in the process of group activities I developed my skills of conversation, vocabulary and the pronunciation of some words.

Lastly, Ismail concluded that he liked the PBL approach because of the teamwork. Adding that he believed every one of the participants had some potentials which could benefit all if carefully coached and given the chance to contribute.

Another finding worth mentioning in the participants' experiences of problem-solving process is their ability to access various resources in gathering information in solving the illstructured problems. The participants mentioned that through the PBL process, they learned to access variety of resource to obtain information and to look at various perspectives before proposing the solutions. For instance, Yunus explained that he learned to access the Internet, library and people's opinions before writing. These findings concur with the proposition of Hmelo-Silver (2004) that PBL helps students to construct an extensive and flexible knowledge and develop effective problem-solving skills, develop self-directed and lifelong learning skills, and become effective collaborators.

\section{Participants' Experiences of PBL in relation to Writing}

In relation to writing skills, the results of the questionnaire also show the participants' positive experiences of PBL. The first item of the questionnaire $(\mathrm{M}=4.66)$ shows that $66.7 \%$ of the participants strongly agreed that the PBL approach improved their writing skills. Specifically, 55.6\% agreed that they improved in the way they plan their writing. More especially, $55.6 \%$ of them strongly agreed that they learned how to generate ideas when planning to write, and $66.7 \%$ strongly agreed that they learned how to edit their writing. In addition, 50\% of them agreed that they learned a lot of English vocabulary from their group members. Thus, $61.1 \%$ of them strongly agreed that their confidence in writing increased. The summary of the result is presented in Table 4 below.

Table 4: Participants' Experiences of PBL in relation to Writing

\begin{tabular}{|c|c|c|c|c|c|c|c|}
\hline No & Item & 2 & 3 & 4 & 5 & Mean & SD \\
\hline 1. & $\begin{array}{l}\text { The PBL activities have improved } \\
\text { my writing skills. }\end{array}$ & & & $33.3 \%$ & $66.7 \%$ & 4.66 & 0.48 \\
\hline 2. & $\begin{array}{l}\text { I learned how to generate ideas } \\
\text { when I write. }\end{array}$ & & & $44.4 \%$ & $55.6 \%$ & 4.55 & 0.51 \\
\hline 3. & $\begin{array}{l}\text { I learned a lot of English } \\
\text { vocabulary from my group } \\
\text { members. }\end{array}$ & $5.6 \%$ & $5.6 \%$ & $50 \%$ & $38.9 \%$ & 4.16 & 0.98 \\
\hline
\end{tabular}




\begin{tabular}{|c|c|c|c|c|c|c|}
\hline 4. & $\begin{array}{l}\text { The activities have increased my } \\
\text { confidence in writing. }\end{array}$ & $11.1 \%$ & $27.8 \%$ & $61.1 \%$ & 4.38 & 0.97 \\
\hline 5. & $\begin{array}{l}\text { I have improved the way I plan my } \\
\text { writing. }\end{array}$ & & $55.6 \%$ & $44.4 \%$ & 4.44 & 0.51 \\
\hline 6. & $\begin{array}{l}\text { I have learned how to edit my } \\
\text { writing. }\end{array}$ & & $33.3 \%$ & $66.7 \%$ & 4.66 & 0.48 \\
\hline
\end{tabular}

The findings from the interviews also show that all the participants felt that PBL affected their writing process positively. According some of the participants, PBL helped them to plan and edit their writing better. They revealed that they learned how to plan and edit their writing better than before. Rabi declared that she improved in planning her writing more than any stage of writing, especially in generating and organising her ideas.

I learned a simple way to brainstorm and outline points on a given topic in a short period of time before putting them down in to paragraphs.

Another participant, Sulaiman explained that he learned how to organise his ideas in writing particularly how to link one idea with another.

Really, it affects my organisation, especially the linkage from one idea to another, one problem to another. I mean from one paragraph to another. I learned different style of arranging my ideas.

Another aspect of the participants' writing which according them had been affected positively the reviewing stage. They believed that through PBL, they learned to revise and improve the content of their writing better than they used to do. Khadija explained that while revising her writing, she used to edit only the grammatical, punctuation and spelling mistakes of her writing, but now she learned to improve the content as well.

\section{Participants' Experiences of PBL in relation to other Language Skills}

The findings show that the participants have positive experiences of PBL in relation to other language skills. With regards to speaking skills, item $1(\mathrm{M}=4.55)$ shows that $72.2 \%$ of the participants strongly agreed that PBL improved their confidence in speaking, while $61 \%$ also strongly agreed that it improved their listening as well as reading skills. This is similar to the findings of Norzaini Azman and Shin (2012) which showed that PBL improves students' language skills. Table 5 presents the results from the questionnaire.

Table 5: Participants' Experiences of PBL in relation to other Language skills

\begin{tabular}{lllllllll}
\hline No & Item & $\mathbf{1}$ & $\mathbf{2}$ & $\mathbf{3}$ & $\mathbf{4}$ & $\mathbf{5}$ & Mean & SD \\
\hline 1. & PBL has improved my confidence in & $5.6 \%$ & & $22.2 \%$ & $72.2 \%$ & 4.55 & 0.98 \\
\hline
\end{tabular}


speaking.

2. PBL has improved my listening ability.

$\begin{array}{rrrrr} & 38.9 \% & 61.1 \% & 4.61 & 0.50 \\ 5.6 \% & 33.3 \% & 61.1 \% & 4.55 & 0.61\end{array}$

3. PBL has improved my reading skills.

During the interview, all the participants agreed that the use of PBL in the writing classroom positively affected not only their writing skills but also the other language skills. For the speaking skills, the participants mentioned that PBL gave them opportunities to practice speaking. They also learned to overcome of their nervousness while speaking in public. According to Binta, PBL gave her the opportunity to speak English publically for a long time which resulted in her overcoming anxiety and improved in her speaking.

Actually, it affects my speaking skills positively because I don't use to speak in English in public only in my native language but now we spend almost two hours speaking in English language now I can speak in front of people without shaking of voice or to feel ashamed that will improve my fluent speaking in the language.

For Indo, the PBL approach also helped to improve her confidence in speaking. Initially she was nervous when talking in the midst of people because she always thought that what she would say would be wrong. Later she realised that they were all learning together. Therefore, she overcame the feelings and started sharing her ideas with her group members. This shows that PBL provides a non-threating environment as Finch (2001) suggests that students' positive change in perceptions occur in a non-threatening learning environment where they feel comfortable to share their ideas with teachers and peers.

Similarly, for Yunus, PBL helped him to overcome his nervousness and also to convince others while speaking.

It has improved my speaking skills because now you are with people that you want to convince. There are ideas you are not only writing the ideas but before you write your ideas other people have to know the ideas and agree with them before it is written down. So, it's like you are mastering or practicing two things, speech delivery skills and how to convince people while you speak to them.

As for the listening skills, the participants mentioned that they improved in their listening skills. They particularly learned to listen attentively during their interactions. In the PBL session, they had to listen well and understand what other members said before they could comment properly. Jibril said:

One must listen to what others say since it is on that he is to add or bring his idea. It is not just to hear but understand.

Ishaq also shared the same view. 
PBL has improved my listening skills too because you are listening for points not just listening, you are listening to make sense of what is being said. So, the point in whatever is said is always my target.

For the reading skills, all of the participants commented that the self-directed learning improved their reading. They always had a reading task after every PBL session which required them to consult various sources and report the findings in a subsequent session. Ismail believed that his reading ability improved as the result of the extensive reading involved in PBL.

It has improved my reading skills because it makes me read widely and extensively whenever a task is given. That makes me write effectively.

Justina also had a similar opinion:

The PBL has positively affected my reading skills because I read more than before I always go home with an activity to do.

To summarise the participants' perceptions and experiences of PBL, it could be seen that the approach was new to them as they were all used to the traditional teacher-centred approach of learning. It was a new but a welcomed development to them. Yunus mentioned

The experience was something new. We usually used to write alone. Usually when writing assignments tests or examination we sit alone, think alone and write alone. But this time we have got friends we have got partners. Sometimes you even lead it. So it was quite exciting and interesting.

Umar also believed that PBL gave him the opportunity to interact with his peers and learn to work collaboratively contrary to the norms of his society. This is similar with the findings of Dochy et al. (2005) in which students perceived PBL as an enhancing learning environment.

Despite the benefits of PBL in the ESL writing classrooms in Nigerian context, as revealed by the study, there are some challenges the participants faced during the PBL activities. One of the problems faced by the participants in relation to the ill-structured problems is that of agreement on the definition of the ill-structured problem at the initial stage of the PBL session. However, with guidance from the tutor, they later agreed on certain definition. The tutor explained that they could have multiple solutions to the problems. Khadija explained:

I didn't understand the question [ill-structured problem] in the first place until the facilitator came and explain it again to the group members there I understand it better.

For Jibril, his problem with one of the ill-structured problems was not that of misunderstanding but of interest. He stated that one of the ill-structured problems was not interesting to him. Therefore, teachers need to consider the interest and cognitive ability of their 
students while formulating the ill-structured problem. This would serve as a motivation to their learning.

Another problem worth mentioning is time factor. The participants complained that PBL is time-consuming, both during the session and during the self-directed learning. During the PBL session, they tended to exceed normal class duration of one to two hours. During the self-directed learning, they also complained lack of sufficient time to carry out all the tasks assigned to them because they had other assignments to do. Teachers should consider these while conducting PBL and help the students to avoid off-topic discussions during the process.

Additionally, the participants faced the problem of unconducive learning environment. They explained that the weather was very hot. Due to the lack of facilities such as air-conditioners and fans in some of the classrooms, learning was not easy for them. In addition, during the selfdirected learning, the participants encountered another problem of limited learning facilities such as books and internet connections. Policy makers and school management should try to provide learning facilities to enable students learn effectively through PBL.

\section{CONCLUSION}

The findings of the present study revealed that the PBL approach is new to the participants in the writing classroom. Despite being a new approach, the findings showed that the participants had positive perceptions and experiences on PBL. It is revealed that most of them preferred the approach be adopted in their ESL courses than their usual traditional teacher-centred approach. The PBL environment can be utilised to enhance not only writing skills but also other language skills as well.

There are some limitations to this study which warrant future studies. Future studies should use larger number or group of students particularly in public universities in Nigeria. In addition, further studies should investigate students' perceptions experiences in learning other aspects of language apart from writing such as speaking, listening and reading through PBL. Additionally, experiences and perceptions of lower level students like secondary school students could also be investigated. Regardless of the limitations, the study shows that PBL could be used in the teaching and learning of writing as students have positive perception of it as it is proven a non-threatening environment (Finch, 2001). The study also shows that PBL provides a good learning environment that promotes language learning, collaborative learning and self-directed learning among students.

\section{REFERENCES}

Ansarimoghaddam, S., \& Tan, B. H. (2014). Undergraduates' experiences and attitudes of writing in L1 and English. GEMA Online: Journal of Language Studies, 14 (1), 7-28.

Babalola, H. A. L. (2012). Effects of process-genre based approach on the written English performance of computer science students in a Nigerian polytechnic. Journal of Education and Practice, 3(6), 1-7.

Bandura, A. (1997). Self-efficacy: The exercise of control. New York: Freeman.

Bigelow, J. D. (2004). Using problem-based learning to develop skills in solving unstructured problems. Journal of Management Education, 28(5), 591-609. 
Bodunde, H. A., \& Sotiloye, B. S. (2013). A critique of undergraduate students' writing skill in an ESL setting: Samples from the Federal University of Agriculture, Abeokuta, Nigeria. World Journal of English Language, 3(2), 10-21.

Creswell, J. W. (2012). Educational Research: Planning, conducting, and evaluating quantitative and qualitative research. 4th edition, Upper Saddle River, NJ, Pearson Merrill Prentice Hall.

Dochy, F., Segers, M., Van Den Bossche, P., \& Struyven, K. (2005). Students' perceptions of a problem-based learning environment. Learning Environments Research 8 (2005) 41-66.

Finch, A. E. (2001). The non-threatening learning environment. Korea TESOL Journal, 4(1), 133 158.

George, D., \& Mallery, P. (2003). SPSS for Windows tep by step: A simple guide and reference. 11.0 update (4th ed.). Boston: Allyn \& Bacon.

Graham, S., \& Harris, K. R. (2009). Evidence-based writing practices: Drawing recommendations from multiple sources. British Journal of Educational Psychology 2(6), 95-111.

Hande, S., Mohammed, C. A., \& Komattil, R. (2014). Acquisition of knowledge, generic skills and attitudes through problem-based learning: Student perspectives in a hybrid curriculum, Journal of Taibah University Medical School, 1 (50), 21-25.

Hmelo-Silver, C. E. (2004). Problem-based learning: what and how do students learn? Educational Psychology Review, 16(3), 235-266.

Hosseini, M., \& Assareh, A. (2011). Life-long learners through problem-based and self directed learning. Procedia Computer Science, 3 (2011), 1446-1453.

Jonassen, D. H. (1997). Instructional design models for well-structured and ill-structured problemsolving learning outcomes. Educational Technology Research and Development, 45(1), 6594.

Mardziah H. Abdullah. (1998). Problem-based learning in language instruction : A constructivist model. ERIC Clearinghouse on Reading English and Communication Bloomington, 1-6.

Mardziah H. Abdullah., \& Tan, B. H. (2008). Wired together: Collaborative problem-pased language learning in an online forum. Malaysia Journal of ELT Research, 4(1), 54-71.

Muodumogu, C. A. \& Unwaha, C. O. (2013). Improving students' achievement in essay writing: What will be the impact of mini-lesson strategy? Global Advanced Research Journal of Arts and Humanities, 2(6), 111-120.

Norman, G. R., \& Schmidt, H. G. (2000). Effectiveness of problem-based learning curricula: Theory, practice and paper darts. Medical education, 34 (9), 721-728.

Norzaini Azman, \& Shin, L. K. (2012). Problem-based learning in English for a second language classroom: Students' perspectives, The International Journal of Learning, 18(6), 109-126.

Obi-Okoye, A. F. (2004). Advanced English composition: The writing process approach. Onitsha: Ganja Books.

Olusoji, O. A. (2013). Effects of bilingualism on the essays of Yoruba/English bilinguals. European Journal of Arts and Humanities, 1(1), 36-47.

Othman, N., \& Ismail Ahamad Shah, M. (2013). Problem-based learning in the English language classroom. English Language Teaching, 6(3), 125-134. 
Rashtchi, M. \& Mohammadi, M. A. (2017). Teaching lexical bundles to improve academic writing via tasks: Does the type of input matter? Electronic Journal of Foreign Language Teaching, 14 (2), 201-219.

Savery, J. R., \& Duffy, T.M. (1995). Problem-based learning: An instructional model and its constructivist framework. In Brent G. Wilson (Ed.) Constructivist learning environments: Case studies in instructional design. New Jersey: Educational Technology Publications.

Schmidt, H. G., Dauphinee, W. D., \& Patel, V. L. (1987). Comparing the effects of problem-based and conventional curricula in an international sample. Academic Medicine, 62(4), 305-15.

Tan, O. S. (2004). Students' experiences in problem-based learning: three blind mice episode or educational innovation? Innovations in Education and Teaching International, 41(2), 169184.

Tarmizi, R. A., \& Bayat, S. (2010). Effects of problem-based learning approach in learning of statistics among university students. Procedia-Social and Behavioural Sciences, 8(2010), 384-392.

Theodore, I. (2013). An appraisal of students' errors in English compositions : Implications for the open and distance learning classroom. International Journal of English and Literature, $4(10), 516-522$.

Wilkerson, L. A., \& Gijselaers, W. H. (Eds) (1996) Bringing problem-based learning to higher education: Theory and practice. San Francisco, CA, Jossey-Bass.

Xiao, Y. (2007). Appling metacognition in EFL writing instruction in China. Reflections on English Teaching, 6: 19-33.

Yuan, H., Kunaviktikul, W., Klunklin, A., \& Williams, B. A. (2008). Improvement of nursing students' critical thinking skills through problem-based learning in the People's Republic of China: A quasi-experimental study. Nursing and Health Sciences, 10(1), 70-76.

Zimmerman, B. J. (1989). A social cognitive view of self-regulated academic learning. Journal of educational psychology, 81(3), 329-339. 


\section{Appendix A}

\section{QUESTIONNAIRE ON STUDENT'S EXPERIENCES OF PROBLEM-BASED LEARNING ACTIVITY IN AN ESL WRITING CLASS}

\section{Dear Student,}

This questionnaire is to obtain your opinions regarding the problem-based learning activity, which you have just completed. The questionnaire is divided into a few sections. Please take your time to read and answer all questions and indicate the extent to which you agree with the statements regarding your experiences. The information that you provide in this questionnaire will be kept confidential and will be used for research purposes only.

Thank you.

Muhammad Mukhtar Aliyu

PhD candidate

Department of English,

Faculty of Modern Languages and Communication,

Universiti Putra Malaysia.

\section{- $\quad$ Respondent's Information}

Check $(\sqrt{ })$ the appropriate box or fill in the requested detail.

Name:

Nationality:

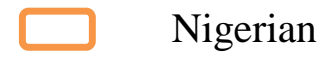

NCE

First

Male

Gender:

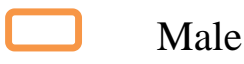

JAMB Score:

SSCE Grade:
Course of study:

Others

Degree

Second $\square$ Third $\square$ Fourth

Female 


\section{- Student's Experiences with Ill-structured Problems}

Instruction: Please tick $(\sqrt{ })$ each statement based on the Likert scale:

$1=$ strongly disagree, $2=$ disagree, $3=$ undecided, $4=$ agree and $5=$ strongly agree

\begin{tabular}{|l|l|l|l|l|l|l|}
\hline & \multicolumn{1}{|l|}{} & $\mathbf{1}$ & $\mathbf{2}$ & $\mathbf{3}$ & $\mathbf{4}$ & $\mathbf{5}$ \\
\hline 1. & $\begin{array}{l}\text { I found the problem well presented in real-life } \\
\text { situation. }\end{array}$ & & & & & \\
\hline 2. & $\begin{array}{l}\text { I found the problem meaningful to the acquisition of } \\
\text { relevant skills for my course. }\end{array}$ & & & & & \\
\hline 3. & $\begin{array}{l}\text { I found the problem meaningful and relevant to the } \\
\text { acquisition of knowledge for my course. }\end{array}$ & & & & & \\
\hline 4. & I was prepared and motivated to work on the problem. & & & & & \\
\hline 5. & $\begin{array}{l}\text { The problem engaged my learning and thinking } \\
\text { throughout the PBL cycle. }\end{array}$ & & & & & \\
\hline 6. & $\begin{array}{l}\text { I learned much through the experience of solving the ill- } \\
\text { structured problem. }\end{array}$ & & & &
\end{tabular}

- $\quad$ Student's Experiences with the Facilitation Process

\begin{tabular}{|l|l|l|l|l|l|l|}
\hline & & $\mathbf{1}$ & $\mathbf{2}$ & $\mathbf{3}$ & $\mathbf{4}$ & $\mathbf{5}$ \\
\hline 1. & $\begin{array}{l}\text { The tutors were confident and knew what they were } \\
\text { doing to facilitate my learning in the PBL process. }\end{array}$ & & & & \\
\hline 2. & $\begin{array}{l}\text { I found the tutors' facilitation throughout the various } \\
\text { PBL stages helpful. }\end{array}$ & & & & & \\
\hline 3. & $\begin{array}{l}\text { I found the tutors' encouragement of inquiry and } \\
\text { questioning helpful. }\end{array}$ & & & & & \\
\hline 4. & $\begin{array}{l}\text { The tutors played a helpful role in facilitating my } \\
\text { acquisition of problem-solving skills. }\end{array}$ & & & & & \\
\hline 5. & $\begin{array}{l}\text { The tutors played a helpful role in facilitating my } \\
\text { acquisition of new knowledge. }\end{array}$ & & & & & \\
\hline 6. & $\begin{array}{l}\text { The tutors played a helpful role in facilitating the } \\
\text { integration of new knowledge. }\end{array}$ & & & & \\
\hline
\end{tabular}


- Student's Experiences as a Problem-solver

\begin{tabular}{|c|c|c|c|c|c|c|}
\hline & & $\mathbf{1}$ & 2 & 3 & 4 & 5 \\
\hline 1. & $\begin{array}{l}\text { I learned to become a more independent and self- } \\
\text { directed learner. }\end{array}$ & & & & & \\
\hline 2. & $\begin{array}{l}\text { I learned to take different perspectives in solving a } \\
\text { problem. }\end{array}$ & & & & & \\
\hline 3. & I learned to think more deeply in solving a problem. & & & & & \\
\hline 4. & $\begin{array}{l}\text { I learned to access a variety of resources and } \\
\text { information in solving a problem. }\end{array}$ & & & & & \\
\hline 5. & $\begin{array}{l}\text { I learned to employ a variety of resources and } \\
\text { information. }\end{array}$ & & & & & \\
\hline 6. & $\begin{array}{l}\text { Through the PBL process I am more prepared and ready } \\
\text { to solve more complex problems. }\end{array}$ & & & & & \\
\hline 7. & $\begin{array}{l}\text { I learned much through the collaborative and co- } \\
\text { operative approaches. }\end{array}$ & & & & & \\
\hline
\end{tabular}

- Student's Experiences of PBL in Relation to Writing in English

\begin{tabular}{|l|l|l|l|l|l|l|}
\hline & \multicolumn{1}{|l|}{} & $\mathbf{1}$ & $\mathbf{2}$ & $\mathbf{3}$ & $\mathbf{4}$ & $\mathbf{5}$ \\
\hline 1. & PBL activity has improved my writing skills. & & & & & \\
\hline 2. & I learnt how to generate ideas when I write. & & & & & \\
\hline 3. & $\begin{array}{l}\text { I learnt a lot of English vocabulary from my group } \\
\text { members. }\end{array}$ & & & & \\
\hline 4. & The activity has increased my confidence in writing. & & & & & \\
\hline 6. & I have improved the way I plan my writing. & & & & & \\
\hline 7. & I have learnt how to edit my writing. & & & & & \\
\hline
\end{tabular}

- Student's Experiences of PBL and Other Language Skills

\begin{tabular}{|l|l|l|l|l|l|l|}
\hline & & $\mathbf{1}$ & $\mathbf{2}$ & $\mathbf{3}$ & $\mathbf{4}$ & $\mathbf{5}$ \\
\hline 1. & PBL has improved my confidence in speaking. & & & & & \\
\hline 2. & PBL has improved my listening ability. & & & & & \\
\hline 3. & PBL has improved my reading skills. & & & & & \\
\hline
\end{tabular}




\section{Appendix B}

\section{Ill-structured Problem 1 (First PBL cycle)}

The recent attacks and abductions of some university students by some terrorist groups in the northern part of the country and the involvement of some university students in terrorism have put fear in some parents and students. This has caused some students, particularly those in that part of the country to transfer their scholarship to other universities while others even abandon schooling completely. What do you think could be done to solve the problem? Collaboratively discuss the problem in your groups following the PBL steps and propose viable solutions to the problem. You are given three weeks to work on the problem with your group members and come up with proposed solutions to the problem.

\section{Ill-structured Problem 2 (Second PBL cycle)}

In recent years, parents, lecturers and government have shown their concern over the poor academic performances and study attitudes of Nigerian undergraduates. Excessive engagement of social media by the undergraduate students has been identified as one of contributing factors to the menace. A recent study by Okechukwu and Ngozi, (2014) has shown that majority of Nigerian undergraduates engage in at least two and above forms of a social media. It has been observed that most of the students spend much of their times on the internet instead of studies. On average, the students spent 6-7 hours on social media a day, as the result, it affects their academic performances and study attitudes negatively.

Propose viable solutions to address this problem following the PBL steps. You are given three weeks to work on the problem with your group members and come up with proposed solutions.

\section{AUTHOR'S BIO:}

Muhammad Mukhtar Aliyu is a lecturer in the Department of English and Literary Studies, Bauchi State University, Gadau, Nigeria. He earned his PhD in English and Applied Linguistics from Universiti Putra Malaysia. His research interests include applied linguistics, collaborative learning and ESL writing.

Yong Mei Fung is a senior lecturer in the Department of English, Faculty of Modern Languages and Communication, Universiti Putra Malaysia. She holds a PhD in Linguistics and Second Language Teaching from Massey University. New Zealand. Her research interests include collaborative writing, blended learning, learner autonomy, and research skill development.

Sabariah Md Rashid is a senior lecturer in the Department of English, Faculty of Modern Languages and Communication, Universiti Putra Malaysia.

Vahid Nimehchisalem is also a senior lecturer in the Department of English, Faculty of Modern Languages and Communication, Universiti Putra Malaysia. 